\title{
The Influence of Organizational Culture and Job Satisfaction on Employee Performance at PT. Mega Sentosa Prima in Jakarta
}

\author{
Nariah \\ Pamulang University, Indonesia \\ Email: dosen02459@unpam.ac.id
}

(Received: December 12-2019; revised: April 15-2020; published: June 31-2020)

\begin{abstract}
Organizational culture has a close relationship with the effectiveness of the organization in achieving its goals. A good organizational culture always impacts on organizational effectiveness. This study aims to determine the effect of organizational culture and job satisfaction on employee performance at PT. Mega Sentosa Prima in Jakarta. The method used is explanatory research with analytical techniques using statistical analysis with regression testing, correlation, determination, and hypothesis testing. The results of this study organizational culture significantly influence employee performance by $42.1 \%$, hypothesis testing obtained $t$ count $>t$ table or (8.335 >> 1.989). Job satisfaction has a significant effect on employee performance by $44.4 \%$, the hypothesis test obtained $t$ count $>t$ table or $(8,764>1,989)$. Organizational culture and job satisfaction simultaneously have a significant effect on employee performance by $53.2 \%$, the hypothesis test is obtained $\mathrm{F}$ count $>\mathrm{F}$ table or $(53.979>2.770)$.
\end{abstract}

Keywords: Organizational culture; job satisfaction; employee performance

\section{INTRODUCTION}

In the current era of globalization business competition between companies is very tight, both for existing companies and new companies operating in Indonesia. On the one hand, the era of globalization is expanding the market for corporate products in Indonesia and on the other hand, this situation has led to increasingly fierce competition between domestic and foreign companies.

Human Resources is the most important thing in a company or organization (Bogataj et al., 2019; Masini, 1990; Sparkes \& Miyake, 2000). Therefore very competent people are needed to achieve the goals of a company. Human Resources is also a driving force in carrying out the implementation of the company's activities. This is what will determine how the company will run going forward. By getting Human Resources by company criteria, it will not rule out the possibility that the company will achieve its goals (Bircan \& Gençler, 2015; Bogataj et al., 2019; Masini, 1990; Nielsen et al., 2005; Sparkes \& Miyake, 2000; Suhariadi, 2013).

In every company there must be a culture, the culture is arguably a custom or habit that is commonly practiced in the company environment. With this culture, it will affect the behavior of employees and culture can also determine the success of a company (Nazarian et al., 2017; Schulman, 2020; Vito, 2020). Organizational culture is inherited or hereditary in a work environment (Jamaluddin et al., 2017; Salam, 2015; Tadampali et al., 2016). The culture brought by a leader, in the beginning, will influence the behavior of his employees and will continue to be continuous even if new employees enter, the culture will remain the same (Sunarsi, 2017; Sunarsi \& Yuliani, 2019). 
152 urnal Administrare: Jurnal Pemikiran Ilmiah dan Pendidikan Administrasi Perkantoran

Vol. 7, No. 1, January - June 2020, Pages 151-60

Organizational culture has a close relationship with the effectiveness of the organization in achieving its goals (Arditi et al., 2017; Copuš et al., 2019; Desselle et al., 2018; Upadhaya et al., 2018). A good organizational culture always impacts on organizational effectiveness. The existence of organizational failure is usually caused by the effectiveness of the organization. Therefore the performance of an employee will be seen from here.

Every company must want Human Resources who have the high ability (Hoendervanger et al., 2019; McDaniel, 1984; Úbeda-García et al., 2018). That way the company's goals will be achieved and profit can also be maximized. However, in some cases, there are still often things that are burdensome to an employee, such as having a job with large responsibilities but with low compensation or also with a lack of company facilities to assist the employee's work. This is what makes an employee feel dissatisfied and the employee's job satisfaction is not achieved.

Job satisfaction has a considerable influence on organizational productivity both directly and indirectly (Kour et al., 2019; Nurhayati et al., 2016; Salau et al., 2018). Dissatisfaction is the starting point for problems that arise in organizations such as absenteeism, manager-worker conflict, and employee turnover. From the worker side, dissatisfaction can cause a decrease in motivation, a decrease in morale, and a decrease in the appearance of work both quantitatively and qualitatively.

An employee's performance is an individual thing because every employee has different levels of ability to carry out their duties (Brown et al., 2015; Song et al., 2019; Wu \& Hou, 2010). A person's performance depends on a combination of abilities, efforts, and opportunities each employee receives. What is meant by performance is an achievement or work result achieved by an employee in carrying out the task and the results can be accounted to superiors.

The number of cases of a company that does not introduce the organizational culture adopted by the company to its employees will have a difficult impact on obtaining a good and positive organizational culture. So that it will spread to other things such as attitudes and behavior, with a lack of employee understanding of the organizational culture adopted by the company does not rule out conflicts between coworkers or employees and superiors. Not paying attention to the needs of employees such as facilities and benefits that are not commensurate with the work and responsibilities assigned to employees will make employees feel dissatisfied with their work and can harm the company. Because it will cause a lot of conflicts such as employee jobs that become bad and miscommunication from superiors.

\section{METHOD}

This type of research used is associative, where the aim is to determine the effect of independent variables on both partial and simultaneous dependent variables. The population in this study amounted to 98 respondents PT. Mega Sentosa Prima in Jakarta. The sampling technique in this study is saturated sampling, where all members of the population are sampled. Thus the sample in this study amounted to 98 respondents. In analyzing the data used the instrument test, classical assumption test, regression, coefficient of determination and hypothesis testing 


\section{RESULT AND DISCUSSION}

Before conducting inferential statistical analysis, first. This test is used to determine the minimum and maximum scores, mean scores, and standard deviations of each variable. The results are as follows:

Table 1.

Descriptive Statistics Analysis Results

Descriptive Statistics

\begin{tabular}{l|r|r|r|r|r}
\hline & N & \multicolumn{1}{|c|}{ Minimum } & Maximum & Mean & \multicolumn{1}{c}{ Std. Deviation } \\
\hline Organizational Culture (X1) & 98 & 32 & 48 & 38.39 & 3.836 \\
\hline Job satisfaction (X2) & 98 & 30 & 45 & 38.40 & 3.685 \\
\hline Employee Performance (Y) & 98 & 32 & 46 & 39.11 & 3.624 \\
\hline Valid N (listwise) & 98 & & & & \\
\hline
\end{tabular}

Organizational culture obtained a minimum variance of 32 and a maximum variance of 48 with a mean score of 3.84 with a standard deviation of 3.836. Job satisfaction obtained a minimum variance of 30 and a maximum variance of 45 with a mean score of 3.84 with a standard deviation of 3.685. Employee performance obtained a minimum variance of 32 and a maximum variance of 46 with a mean score of 3.91 with a standard deviation of 3.624.

\section{The Influence of Organizational Culture on Employee Performance}

Correlation coefficient analysis is intended to determine the level of strength of the relationship between organizational culture variables on employee performance variables. The test results are as follows:

Table 2.

Correlation Coefficient Testing Results Organizational Culture Against Employee Performance

\begin{tabular}{llr|r}
\hline & \multicolumn{2}{c}{ Correlations $^{\mathbf{b}}$} \\
& \multicolumn{1}{c}{$\begin{array}{c}\text { Organizational } \\
\text { Culture (X1) }\end{array}$} & $\begin{array}{c}\text { Employee } \\
\text { Performance (Y) }\end{array}$ \\
\hline Organizational Culture (X1) & Pearson Correlation & 1 & $.649^{* *}$ \\
\cline { 2 - 4 } & Sig. (2-tailed) & & .000 \\
\hline Employee Performance (Y) & Pearson Correlation & $.649^{* *}$ & 1 \\
\cline { 2 - 4 } & Sig. (2-tailed) & .000 & \\
\hline
\end{tabular}

**. Correlation is significant at the 0.01 level (2-tailed).

b. Listwise $\mathrm{N}=86$

Based on the test results obtained a correlation value of 0.649 means that organizational culture has a strong relationship to employee performance.

The coefficient of determination analysis is intended to determine the percentage of influence of organizational culture variables on employee performance variables either partially or simultaneously. The test results are as follows: 
154 Jurnal Administrare: Jurnal Pemikiran Ilmiah dan Pendidikan Administrasi Perkantoran Vol. 7, No. 1, January - June 2020, Pages 151-6o

Table 3.

Determination Coefficient Test Results from the Organizational Culture of Employee Performance

\begin{tabular}{l|cr|cr|r}
\hline \multicolumn{8}{c}{ Model Summary } \\
\hline Model & R & \multicolumn{2}{c}{$\begin{array}{c}\text { Adjusted R } \\
\text { Square }\end{array}$} & \multicolumn{2}{c}{$\begin{array}{c}\text { Std. Error of the } \\
\text { Estimate }\end{array}$} \\
\hline 1 & $.649^{\mathrm{a}}$ & R Square & .421 & .415 & 2.772 \\
\hline
\end{tabular}

a. Predictors: (Constant), Organizational Culture (X1)

Based on the test results obtained a determination value of 0.421 means that organizational culture has an influence contribution of $42.1 \%$ on employee performance

Hypothesis testing with a t-test is used to find out which partial hypotheses are accepted. First hypothesis: there is a significant influence between organizational culture on employee performance.

Table 4.

Hypothesis Test Results of Organizational Culture on Employee Performance Coefficients $^{\mathrm{a}}$

\begin{tabular}{ll|r|r|r|r}
\hline & \multicolumn{2}{c|}{$\begin{array}{c}\text { Unstandardized } \\
\text { Coefficients }\end{array}$} & $\begin{array}{l}\text { Standardized } \\
\text { Coefficients }\end{array}$ & & \\
Model & \multicolumn{1}{c|}{ B } & Std. Error & Beta & \multicolumn{1}{c|}{ t } & \multicolumn{1}{c}{ Sig. } \\
\hline $1 \quad$ Constant) & 15.585 & 2.831 & & 5.506 & .000 \\
\hline $\begin{array}{l}\text { Organizational Culture } \\
\text { (X1) }\end{array}$ & .613 & .073 & .649 & 8.353 & .000 \\
\hline
\end{tabular}

a. Dependent Variable: Employee Performance (Y)

Based on the test results in the table above, obtained the value of $t$ count $>t$ table or (8.335> 1.989), thus the first hypothesis proposed that there is a significant influence between organizational culture on employee performance is accepted.

\section{The Influence of Job Satisfaction on Employee Performance}

Correlation coefficient analysis is intended to determine the level of strength of the relationship of the variable job satisfaction on employee performance variables. The test results are as follows: 
Table 5.

Correlation Coefficient Test Results Job satisfaction on Employee Performance Correlations $^{\mathrm{b}}$

\begin{tabular}{llr|r}
\hline & & $\begin{array}{c}\text { Job satisfaction } \\
(\mathrm{X} 2)\end{array}$ & \multicolumn{1}{c}{$\begin{array}{c}\text { Employee } \\
\text { Performance (Y) }\end{array}$} \\
\hline Job satisfaction (X2) & Pearson Correlation & 1 & $.667^{* *}$ \\
\cline { 2 - 4 } & Sig. (2-tailed) & & .000 \\
\hline Employee Performance (Y) & Pearson Correlation & $.667^{* *}$ & 1 \\
\cline { 2 - 4 } & Sig. (2-tailed) & .000 & \\
\hline
\end{tabular}

**. Correlation is significant at the 0.01 level (2-tailed).

b. Listwise $\mathrm{N}=86$

Based on the test results obtained a correlation value of 0.667 means that job satisfaction has a strong relationship with employee performance.

Analysis of the coefficient of determination is intended to determine the percentage of influence of the variable job satisfaction on employee performance variables either partially or simultaneously. The test results are as follows:

Table 6.

Test Results Determination Coefficient Job satisfaction on Employee Performance Model Summary

\begin{tabular}{|c|c|c|c|c|}
\hline Model & $\mathrm{R}$ & R Square & $\begin{array}{l}\text { Adjusted R } \\
\text { Square }\end{array}$ & $\begin{array}{l}\text { Std. Error of the } \\
\text { Estimate }\end{array}$ \\
\hline 1 & $.667^{\mathrm{a}}$ & .444 & .439 & 2.715 \\
\hline
\end{tabular}

a. Predictors: (Constant), Employee Performance (X2)

Based on the test results obtained a determination value of 0.444 means that job satisfaction has an influence contribution of $44.4 \%$ on employee performance.

Hypothesis testing with a t-test is used to find out which partial hypotheses are accepted. First Hypothesis: There is a significant influence on job satisfaction on employee performance.

Table 7.

Hypothesis Test Results Job satisfaction with Employee Performance

\section{Coefficients}

\begin{tabular}{|c|c|c|c|c|c|}
\hline \multirow[b]{2}{*}{ Model } & \multicolumn{2}{|c|}{$\begin{array}{l}\text { Unstandardized } \\
\text { Coefficients }\end{array}$} & \multirow{2}{*}{$\begin{array}{l}\text { Standardized } \\
\text { Coefficients } \\
\text { Beta }\end{array}$} & \multirow[b]{2}{*}{$\mathrm{t}$} & \multirow[b]{2}{*}{ Sig. } \\
\hline & $\mathrm{B}$ & Std. Error & & & \\
\hline $1 \quad$ (Constant) & 13.942 & 2.885 & & 4.832 & .000 \\
\hline Job satisfaction (X2) & .656 & .075 & .667 & 8.764 & .000 \\
\hline
\end{tabular}

a. Dependent Variable: Employee Performance (Y)

Based on the test results in the table above, the value of $t$ count $>t$ table or $(8.764>1.989)$ is obtained, thus the second hypothesis is proposed that there is a significant influence between job satisfaction on employee performance received. 
156 Jurnal Administrare: Jurnal Pemikiran Ilmiah dan Pendidikan Administrasi Perkantoran Vol. 7, No. 1, January - June 2020, Pages 151-60

\section{The Influence of Organizational Culture and Job Satisfaction on Employee Performance}

Correlation coefficient analysis is intended to determine the level of strength of the relationship between organizational culture variables and job satisfaction with employee performance variables. The test results are as follows:

Table 8.

Test Results Correlation Coefficient Organizational culture and job satisfaction simultaneously on employee performance

\begin{tabular}{|c|c|c|c|c|}
\hline \multicolumn{5}{|c|}{ Model Summary } \\
\hline Model & $\mathrm{R}$ & R Square & $\begin{array}{l}\text { Adjusted R } \\
\text { Square }\end{array}$ & $\begin{array}{l}\text { Std. Error of the } \\
\text { Estimate }\end{array}$ \\
\hline 1 & $.729^{\mathrm{a}}$ & .532 & .522 & 2.505 \\
\hline
\end{tabular}

a. Predictors: (Constant), Job Satisfaction (X2), Organizational Culture (X1)

Based on the test results obtained a correlation value of 0.729 means that organizational culture and job satisfaction simultaneously have a strong relationship to employee performance.

Analysis of the coefficient of determination is intended to determine the percentage of influence of the variable job satisfaction on employee performance variables either partially or simultaneously. Based on the test results obtained a determination value of 0.532 means that organizational culture and job satisfaction simultaneously have an influence contribution of $53.2 \%$ on employee performance, while the remaining $46.8 \%$ is influenced by other factors.

This regression test is intended to determine changes in the dependent variable if the independent variable changes. The test results are as follows:

Table 9.

Multiple Linear Regression Testing Results

Coefficients $^{\mathrm{a}}$

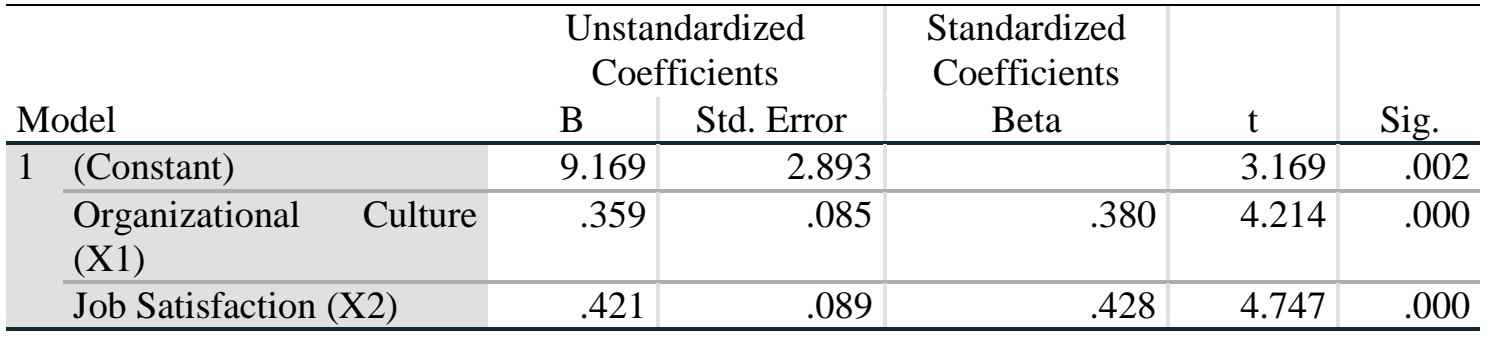

a. Dependent Variable: Employee Performance (Y)

Based on the test results in the above table, the regression equation $Y=9,169+0,359 \mathrm{X} 1+$ $0,421 \mathrm{X} 2$ is obtained. From the equation, it is explained that a constant of 9,169 means that if there is no organizational culture and job satisfaction, then there is an employee performance value of 9,169 points. The regression coefficient of organizational culture is 0.359 , this number is positive meaning that every time there is an increase in organizational culture by 0.359 , employee performance will also increase by 0.359 points. The job satisfaction regression coefficient is 0.421 , this number is positive, meaning that every time there is an increase in job 
satisfaction by 0.421 , the employee's performance will also increase by 0.421 points.

Hypothesis testing with the $\mathrm{F}$ test is used to find out which simultaneous hypotheses are accepted. The third hypothesis: there is a significant influence between organizational culture and job satisfaction on employee performance.

Table 10.

Hypothesis Test Results Organizational Culture and Job Satisfaction on Employee Performance

ANOVA $^{\mathrm{a}}$

\begin{tabular}{llr|r|r|r|r}
\hline Model & & Sum of Squares & \multicolumn{1}{c}{ df } & Mean Square & \multicolumn{1}{c}{ F } & \multicolumn{1}{c}{ Sig. } \\
\hline 1 & Regression & 677.546 & 2 & 338.773 & 53.979 & $.000^{\mathrm{b}}$ \\
\cline { 2 - 7 } & Residual & 596.219 & 95 & 6.276 & \\
\cline { 2 - 7 } & Total & 1273.765 & 97 & & & \\
\hline
\end{tabular}

Based on the test results in the above table, the calculated $F$ value $>F$ table or (53.979> 2.770), thus the third hypothesis proposed that there is a significant influence between organizational culture and job satisfaction on employee performance is accepted.

\section{Discussion}

\section{The Influence of Organizational Culture on Employee Performance}

Organizational culture has a significant effect on employee performance with a correlation of 0.649 or has a strong relationship with a contribution of $42.1 \%$. Hypothesis testing obtained $t$ count $>t$ table or $(8.335>1.989)$. Thus the first hypothesis proposed that there is a significant effect between organizational culture on employee performance is accepted.

\section{The Influence of Job Satisfaction on Employee Performance}

Job satisfaction has a significant effect on employee performance with a correlation of 0.667 or has a strong relationship with a contribution of $44.4 \%$. Hypothesis testing obtained $t$ count $>\mathrm{t}$ table or $(8.764>1.989)$. Thus the second hypothesis proposed that there is a significant effect between job satisfaction on employee performance is accepted

\section{The Influence of Organizational Culture and Job Satisfaction on Employee Performance}

Organizational culture and job satisfaction have a significant effect on employee performance by obtaining a regression equation $\mathrm{Y}=9,169+0,359 \mathrm{X} 1+0,421 \mathrm{X} 2$, the correlation value of 0.729 , or having a strong relationship with the contribution of effect of $53.2 \%$ while the remaining $46.8 \%$ is influenced by factors other. Hypothesis testing obtained by calculating the $\mathrm{F}$ count $>\mathrm{F}$ table or $(53.979>2.770)$. Thus the third hypothesis proposed that there is a significant effect between organizational culture and job satisfaction on employee performance is accepted. 
158 Jurnal Administrare: Jurnal Pemikiran Ilmiah dan Pendidikan Administrasi Perkantoran

Vol. 7, No. 1, January - June 2020, Pages 151-6o

\section{CONCLUSION}

Organizational culture has a significant effect on employee performance with an influence contribution of $42.1 \%$. Hypothesis testing obtained values of $t$ count $>t$ table or (8.335>1.989). Job satisfaction has a significant effect on employee performance with an influence contribution of $44.4 \%$. Hypothesis testing obtained $t$ count $>t$ table or (8.764> 1.989). Organizational culture and job satisfaction have a significant effect on employee performance with a contribution of $53.2 \%$ while the remaining $46.8 \%$ is influenced by other factors. Hypothesis testing obtained the value of $\mathrm{F}$ count $>\mathrm{F}$ table or $(53.979>2.770)$.

\section{REFERENCES}

Arditi, D., Nayak, S., \& Damci, A. (2017). Effect of organizational culture on delay in construction. International Journal of Project Management, 35(2), 136-147. https://doi.org/https://doi.org/10.1016/j.ijproman.2016.10.018

Bircan, İ., \& Gençler, F. (2015). Analysis of Innovation-Based Human Resources for Sustainable Development. Procedia - Social and Behavioral Sciences, 195, 1348-1354. https://doi.org/https://doi.org/10.1016/j.sbspro.2015.06.321

Bogataj, D., Bogataj, M., \& Drobne, S. (2019). Interactions between flows of human resources in functional regions and flows of inventories in dynamic processes of global supply chains. International Journal of Production Economics, 209, 215-225. https://doi.org/https://doi.org/10.1016/j.ijpe.2017.10.018

Brown, S., Gray, D., McHardy, J., \& Taylor, K. (2015). Employee trust and workplace performance. Journal of Economic Behavior \& Organization, 116, 361-378. https://doi.org/https://doi.org/10.1016/j.jebo.2015.05.001

Copuš, L., Šajgalíková, H., \& Wojčák, E. (2019). Organizational Culture and its Motivational Potential in Manufacturing Industry: Subculture Perspective. Procedia Manufacturing, 32, 360-367. https://doi.org/https://doi.org/10.1016/j.promfg.2019.02.226

Desselle, S. P., Raja, L., Andrews, B., \& Lui, J. (2018). Perceptions of organizational culture and organizational citizenship by faculty in U.S. colleges and schools of pharmacy. Currents in Pharmacy Teaching and Learning, 10(4), 403-412. https://doi.org/https://doi.org/10.1016/j.cptl.2017.12.017

Hoendervanger, J. G., Van Yperen, N. W., Mobach, M. P., \& Albers, C. J. (2019). Perceived fit in activity-based work environments and its impact on satisfaction and performance. $\begin{array}{lllll}\text { Journal of Environmental } & \text { Psychology, } & 65, & 101339 .\end{array}$ https://doi.org/https://doi.org/10.1016/j.jenvp.2019.101339

Jamaluddin, J., Salam, R., Yunus, H., \& Akib, H. (2017). Pengaruh Budaya Organisasi terhadap Kinerja Pegawai pada Dinas Pendidikan Provinsi Sulawesi Selatan. Jurnal Ad'ministrare, 
$4(1), 25-34$.

Kour, J., El-Den, J., \& Sriratanaviriyakul, N. (2019). The Role of Positive Psychology in Improving Employees' Performance and Organizational Productivity: An Experimental Study. Procedia Computer Science, 161, 226-232. https://doi.org/https://doi.org/10.1016/j.procs.2019.11.118

Masini, E. B. (1990). Human Resources in Developing Countries. Futures, 22(10), 1037-1043. https://doi.org/https://doi.org/10.1016/0016-3287(90)90005-3

McDaniel, D. (1984). Human resources development for communications in the Third World. Telematics and Informatics, 1(2), 141-146. https://doi.org/https://doi.org/10.1016/S07365853(84)80004-0

Nazarian, A., Atkinson, P., \& Foroudi, P. (2017). Influence of national culture and balanced organizational culture on the hotel industry's performance. International Journal of Hospitality Management, $\quad 63, \quad 22-32$. https://doi.org/https://doi.org/10.1016/j.jhm.2017.01.003

Nielsen, J., Andreasen, A., \& Alexander, A. (2005). Promotion of work ability at company level: Intention and performance, dreams and realities. International Congress Series, 1280, 386-391. https://doi.org/https://doi.org/10.1016/j.ics.2005.02.093

Nurhayati, M. N., Siti Zawiah, M. D., \& Mahidzal, D. (2016). The relationship between work productivity and acute responses at different levels of production standard times. International Journal of Industrial Ergonomics, 56, 59-68. https://doi.org/https://doi.org/10.1016/j.ergon.2016.09.009

Salam, R. (2015). Penerapan Fungsi Administrasi Perkantoran Modern berbasis Daya Saing Organisasi dalam menyongsong MEA 2015. SEMINAR NASIONAL "Revolusi Mental Dan Kemandirian Bangsa Melalui Pendidikan Ilmu-Ilmu Sosial Dalam Menghadapi MEA 2015” Himpunan Sarjana Pendidikan Ilmu-Ilmu Sosial Indonesia, 1, 186-190.

Salau, O., Worlu, R., Osibanjo, A., Adeniji, A., Oludayo, O., \& Falola, H. (2018). Survey data on work environments and productivity of academic staff of selected public universities in $\begin{array}{lllll}\text { Nigeria. Data in } & \text { Brief, } & 1912-1917 .\end{array}$ https://doi.org/https://doi.org/10.1016/j.dib.2018.06.074

Schulman, P. R. (2020). Organizational structure and safety culture: Conceptual and practical

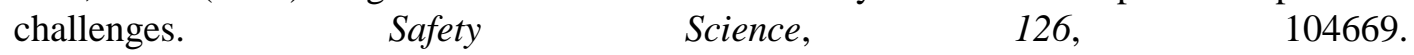
https://doi.org/https://doi.org/10.1016/j.ssci.2020.104669

Song, Q., Wang, Y., Chen, Y., Benitez, J., \& Hu, J. (2019). Impact of the usage of social media in the workplace on team and employee performance. Information \& Management, 103160. https://doi.org/https://doi.org/10.1016/j.im.2019.04.003

Sparkes, J. R., \& Miyake, M. (2000). Knowledge transfer and human resource development practices: Japanese firms in Brazil and Mexico. International Business Review, 9(5), 599612. https://doi.org/https://doi.org/10.1016/S0969-5931(00)00021-4 
160 Jurnal Administrare: Jurnal Pemikiran Ilmiah dan Pendidikan Administrasi Perkantoran Vol. 7, No. 1, January - June 2020, Pages 151-6o

Suhariadi, F. (2013). Manajemen Sumber Daya Manusia: Dalam Pendekatan Teoritis-Praktis. Airlangga University Press.

Sunarsi, D. (2017). Pengaruh Kepemimpinan Dan Budaya Organisasi terhadap Kinerja Karyawan Pada Cabang Pembantu Bank DKI Pondok Labu - Jakarta Selatan. JENIUS, $1(2), 21$.

Sunarsi, D., \& Yuliani, I. (2019). Pengaruh Gaya Kepe Mimpinan Dan Budaya Organisasi Terhadap Kinerja Karyawan Pada Bank BTN KANTOR CABANG TANGERANG. Jurnal Semarak, 2(1).

Tadampali, A. C. T., Hadi, A., \& Salam, R. (2016). Pengaruh Iklim Organisasi terhadap Turnover Intention Melalui Kepuasan Kerja sebagai Variabel Intervening pada PT Bank SulSelBar. Jurnal Ilmiah Ilmu Administrasi Publik, 6(2), 35-46.

Úbeda-García, M., Claver-Cortés, E., Marco-Lajara, B., Zaragoza-Sáez, P., \& García-Lillo, F. (2018). High performance work system and performance: Opening the black box through the organizational ambidexterity and human resource flexibility. Journal of Business Research, 88, 397-406. https://doi.org/https://doi.org/10.1016/j.jbusres.2017.12.045

Upadhaya, B., Munir, R., Blount, Y., \& Su, S. (2018). Does organizational culture mediate the CSR - strategy relationship? Evidence from a developing country, Nepal. Journal of Business Research, 91, 108-122. https://doi.org/https://doi.org/10.1016/j.jbusres.2018.05.042

Vito, R. (2020). Key variations in organizational culture and leadership influence: A comparison between three children's mental health and child welfare agencies. Children $\begin{array}{lllll}\text { and } \quad \text { Youth } \quad \text { Services } & 104600 .\end{array}$ https://doi.org/https://doi.org/10.1016/j.childyouth.2019.104600

Wu, Y.-J., \& Hou, J.-L. (2010). An employee performance estimation model for the logistics industry. Decision Support Systems, 48(4), 568-581. https://doi.org/https://doi.org/10.1016/j.dss.2009.11.007 